\title{
Estimation of Safe Yield of a Multipurpose Reservoir Using Weap: A Case Study of Thwake Reservoir, Makueni and Kitui Counties, Kenya
}

\author{
Christine Nyanchoka Ochengo*, Stephen Conrad Ondieki, John Paul Obiero \\ Department of Environmental and Biosystems Engineering, University of Nairobi, Nairobi, Kenya \\ Email address: \\ tinaochengo@gmail.com (C. N. Ochengo) \\ *Corresponding author \\ To cite this article: \\ Christine Nyanchoka Ochengo, Stephen Conrad Ondieki, John Paul Obiero. Estimation of Safe Yield of a Multipurpose Reservoir Using \\ Weap: A Case Study of Thwake Reservoir, Makueni and Kitui Counties, Kenya. Journal of Water Resources and Ocean Science. \\ Vol. 7, No. 4, 2018, pp. 60-69. doi: 10.11648/j.wros.20180704.11
}

Received: August 13, 2018; Accepted: August 24, 2018; Published: October 29, 2018

\begin{abstract}
WEAP (Water Evaluation And Planning) is an integrated water resources planning model developed for more than 25 years by the Stockholm Environment Institute (SEI). In the WEAP model, dam and the water demands (upstream and downstream) are all schematized as an interconnected system ruled by allocation priorities (e.g., dam operation rules, priority for competing demands such as water supply, irrigation, hydropower, environmental flow, water storage in the reservoir). Thwake Reservoir is a multipurpose reservoir for hydropower generation, water supply and irrigation development in Kitui and Makueni Counties. The counties are well known as semi-arid hence the key objective of the study is to estimate the safe yield of the reservoir to enhance effective allocation of the water for different competing demands. Safe yield is based on projected future conditions that include a repeat of the most severe drought of record. Because the definition refers to projected future conditions, safe yield is inherently an estimated characteristic of future conditions that cannot currently be observed or measured. Thus any safe yield is only theoretically available at the time of the estimate. However, the reference to a repeat of the most severe drought of record indicates that past conditions are to be used to project future conditions. In this regard, 1000 years' synthetic flows were generated using SWAT Model. In the model, 61 years (1952-2012) historical flows were used and the projected flows input into the WEAP model. The monthly reservoir balance for the base scenario and upstream dams development scenario were simulated. The performance of the Thwake Reservoir under different scenarios was assessed. Different sets of scenarios were explored for the Base Case and upstream development dams. These sets were tuned to the operational rules of the Thwake reservoir. Eventually, the dependable yield of the reservoir under different operating rules was estimated for both the base case and the upstream dam development scenarios. Thwake reservoir has an estimated dependable yield when it will be in operation before and after the development of the upstream dams.
\end{abstract}

Keywords: Model, Reservoir, WEAP, SWAT

\section{Introduction}

\subsection{Study Area}

Thwake multi-purpose dam is a flagship Project in the National Water Master Plan 2030. The proposed Thwake dam site is located approximately $1 \mathrm{~km}$ downstream of the confluence of rivers Thwake and Athi. The axis of the proposed dam runs across the Athi River and when implemented will connect Makueni and Kitui Counties. The coordinates of the site obtained using a hand held GPS set are $01^{\circ} 47.150^{\circ} \mathrm{S}$ and $37^{\circ} 50.562^{\circ} \mathrm{E}$. The altitude of the site is approximately $840 \mathrm{~m}$ above sea level (m.a.s.l). The highest point of the catchment is at 2,600 m.a.s.l. Athi Catchment upstream of the dam site extends across four administrative provinces - Central, Nairobi, Eastern and Rift Valley. The following counties are within the catchment i.e Nairobi, Kiambu, Machakos, Kajiado, Makueni and Kitui. Included within the catchment is Nairobi City, Athi River Township and large parts of Kajiado County. It covers an area of 7,429 
$\mathrm{km}^{2}$. The catchment area associated with river Thwake is largely the semi-arid area to the South East of Nairobi. It covers an area of approximately $2,847 \mathrm{~km}^{2}$. The total combined catchment area is therefore $10,276 \mathrm{~km}^{2}(17.5 \%$ of the Athi Catchment Area) with $35 \%$ in arable lands and $65 \%$ in semi arable lands.

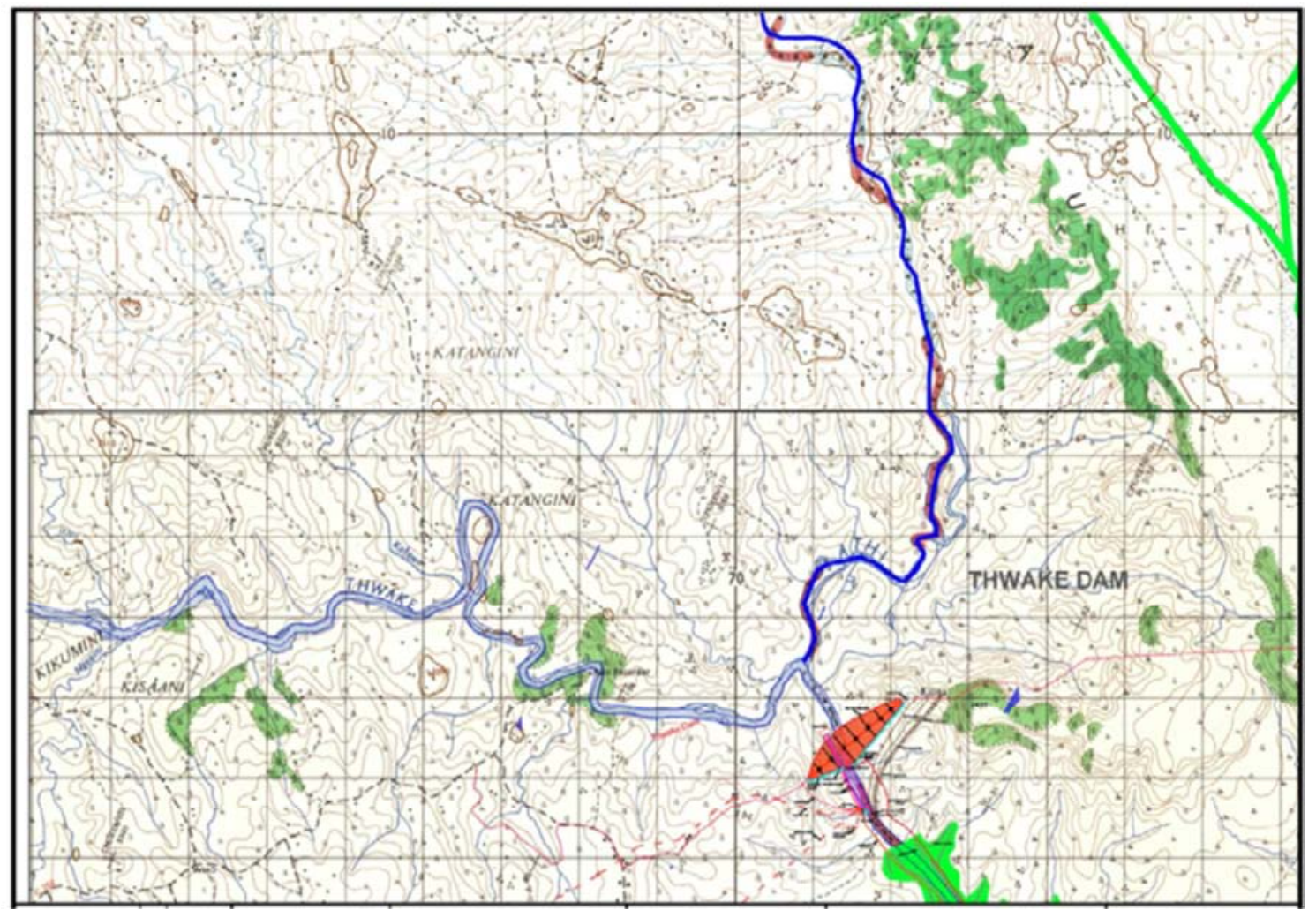

Figure 1. Thwake dam location.

\subsection{Modelling Using WEAP}

WEAP is a user-friendly software tool that is developed by the Stockholm Environmental institute (SEI) to assist decision makers in managing water demand, water availability, waste generation and water costs and to evaluate water development and management options

WEAP (Water Environment And Planning) is a practical tool for water resources planning which incorporates not only water supply-side and water demand-side issues, but also water quality and ecosystem preservation issues, by its integrated approach to simulate water systems and by its policy orientation [1]. In Kenya WEAP has been applied in various ways. [2] used WEAP for water demand simulation a case study of Mara River. [3] also Modeled Water Demand and Efficient Use in Mbagathi Sub-Catchment Using Weap.

WEAP also has an integration nature where the dam and the water demands (upstream and downstream) can be all schematized as an interconnected system ruled by allocation priorities (e.g., dam operation rules, priority for competing demands such as water supply, irrigation, hydropower, environmental flow, water storage in the reservoir), [4]

A brief review of literature shows different methods of generating the synthetic flows. For example, [5] generated synthetic flows using the method of fragments. This procedure involves generating synthetic series of annual and monthly flows that combines two models, a probabilistic one, applied at an annual level, and at a monthly level, a deterministic disaggregation mode. [6] used the modified Thomas Fiering Model to calculate streamflow simulation and synthetic flow.

United States Department of Agriculture (USDA) produced SWAT model, which is a continuous-time, semidistributed, process-based model, developed to evaluate the effects of alternative management decisions on water resources and nonpoint-source pollution in large river basins [7].

\subsection{Problem Statement and Objectives}

The Thwake multi-purpose dam is a flagship Project in the National Water Master Plan 2030. Its main use being irrigation and water supply. The release of the two uses will be used for hydropower generation. The dam thus has to satisfy water demands, irrigation demand, environmental flow demand and the hydropower demand.

From the previous studies, the different demands for the Multi-purpose dam have been estimated. However, the safe yield of the dam is unknown. In the recent past, dams (reservoirs) have failed to meet the intended demands even before half of their lifetime. This has caused major deficiency in the demands and hence affected the reliability. Water shortages and poor or even no distribution to competing demands has been experienced due to unknown safe yield of 
the reservoir Safe yield is the maximum, sustainable, continuous withdrawal that can be made from a reservoir at any given time. Given the many competing demands from the Thwake Reservoir, estimating the reservoir safe yield will help know the general reliability of the reservoir to supply the different competing demands at a particular time. In this regard, the study is motivated by the fact that at the end of the study the safe yield of the reservoir under a range of hydrological- and catchment management conditions will be identified. This will entail the priorities and constraints that the reservoir operator will consider when making releases.

\section{Methododology}

\subsection{Inflow and Outflow Requirement for Thwake Reservoir}

To establish the inflow and outflow requirement for Thwake Reservoir, the following data was necessary and hence was collected and analysed accordingly.

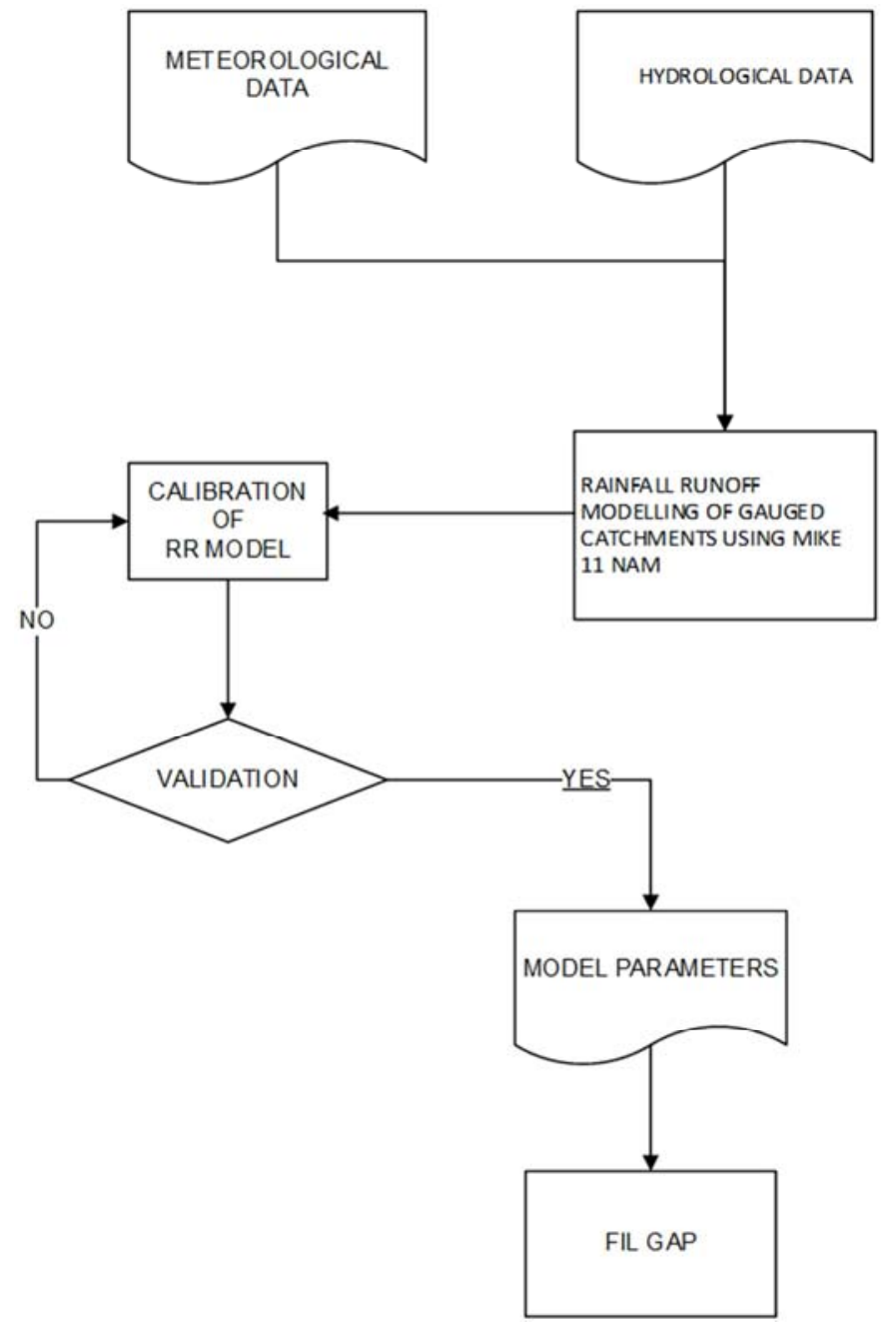

LEGEND

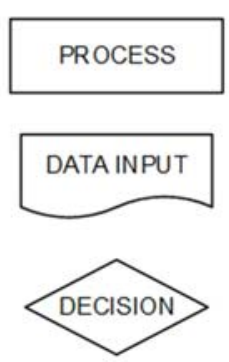

Figure 2. Simplified flow chart for filling gaps using MIKE 11.

The trend analysis of flow at RGS 3F02 to test for any major changes in the flow regime due to catchment changes was also undertaken. The analysis was undertaken through mass curve analysis and normal trend observation of the

\subsubsection{Stream Flows (Inflow) Requirement}

The daily river flow data at River gauging station 3F02 (Athi River at Mavindini) which is within the dam site was collected from the Water Resources Management Authority (WRMA), for 61 years (1952 to 2012). This data however showed some gaps which were filled using MIKE 11 rainfall runoff model, using the data obtained from WARMA. MIKE 11 rainfall runoff model application was divided into three (3) stages. The first stage was the calibration process to determine optimal values of the model parameters. The second stage was the validation of the model parameters using a different set of data not used in calibrating the model. The third stage was stream flow simulation using the estimated optimal model parameters obtained during the calibration process. A simplified flow chart of the methodology adopted for filling of the gaps is presented in figure 2 below. 


\subsubsection{Water Demand Data (Outflow Requirement)}

(a) Domestic water demand

(b) This included domestic water for extended Wote system, Konza city and its environs. This data was collected from previous reports [8]

(c) Hydropower water demand

The demand is to facilitate the electricity production to activate the water pumps required for the Konza domestic water supply. This data was collected from previous reports provided by the Ministry of Water and Irrigation. [9]

(d) Environmental flow water demand

This is the flow released for the downstream users. Under this study the environmental flow was set at $95 \%$ exceedance probability.

(e) Galana flow requirement
This is the irrigation requirement for Galana Kulalu irrigation project. Part of the project will be supplied by Thwake Reservoir. Thus Thwake dam will release water for this downstream scheme to satisfy what will be referred in this thesis as the "Galana flow requirement". This data was collected from previous reports provided by the Ministry of Water and Irrigation [10].

(f) Irrigation water Requirement

This includes irrigation requirement for irrigation area I (Net irrigation area 2,377ha) and irrigation area II (Net irrigation area 9,065ha). The irrigation requirement was in 1/ha/s. These areas are located downstream of the Thwake Reservoir and crops under irrigation include beans, foodcrops fruits and vegetables. This data was collected from previous studies [11].

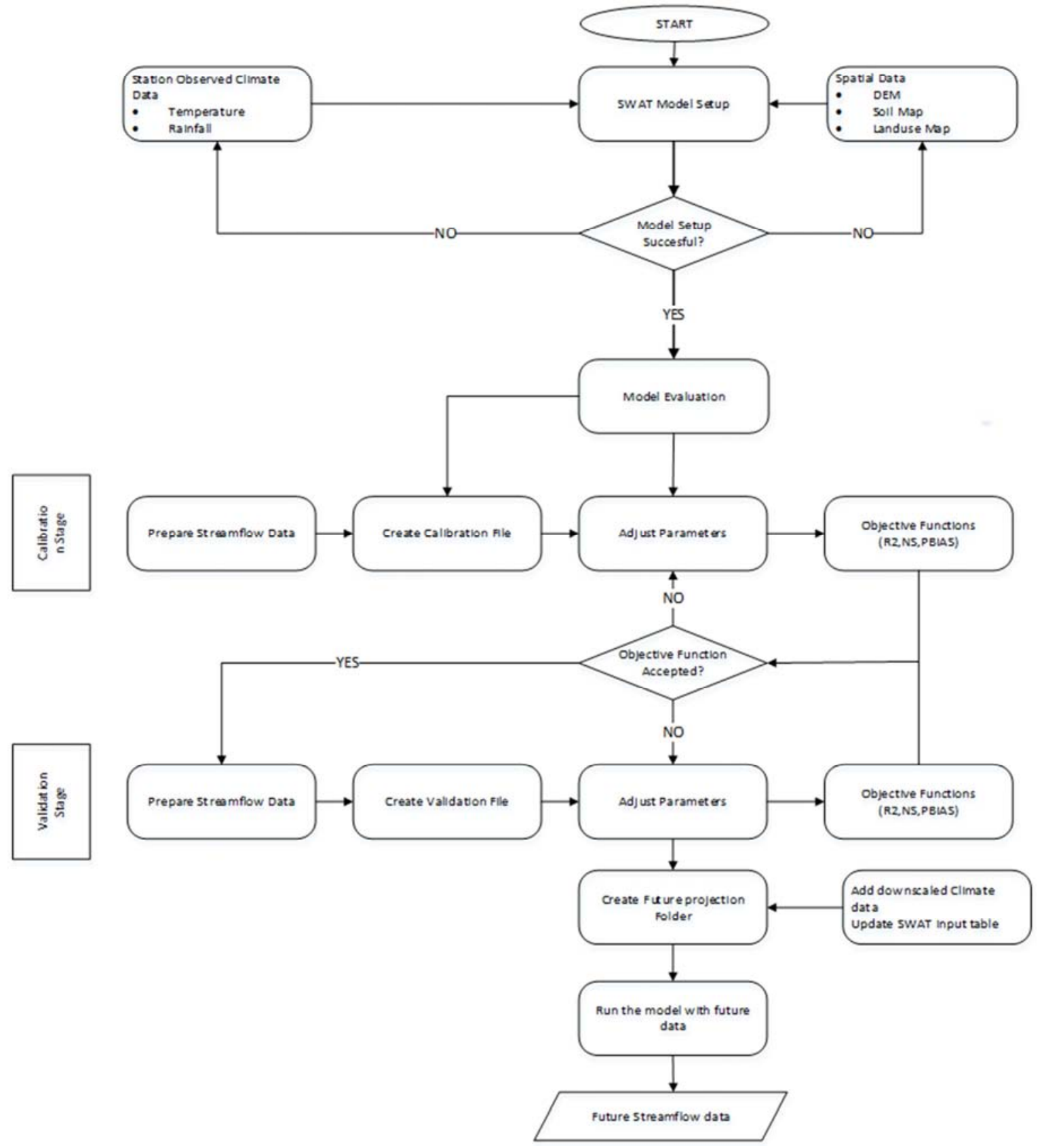

Figure 1. Framework of the study for the generation of future flows. 


\subsection{Simulation of Synthetic Flow}

Generation of correlated synthetic time series of monthly inflows for Thwake Dam was done using SWAT Model. This was done for 1000 synthetic hydrologic years. The methodological framework followed for the simulation of synthetic flow is as shown in Figure 3 and involved:

$i$ the preparation of spatial and climate data into SWAT format;

ii model setup, including watershed delineation and Hydrologic Response Units (HRUs) definition;

iii model calibration and validation;

iv downscaling of climate variables; and

$\mathrm{V}$ Application into the hydrologic model.

The SWAT model requires observed climate and spatial data to force the rainfall-runoff simulation process. The results of model performance for stream-flow at 3FO2 gauging station were given in terms of the 2 objective functions for both calibration and validation periods.

The data used for calibration was data from 1976 to 1979 , while for validation the data from 1980 to 1984 was used. Model performance was evaluated using the Sequential Uncertainty Fitting algorithm (SUFI-2) component within SWAT-CUP tool version 5.1.6. The parallel processing option of the SWAT-CUP helped to expedite the calibration process by reducing the overall processing time.

Detailed information about the data used, including the data type and their source, is presented in table 1 below.

Table 1. Data Requirement and source.

\begin{tabular}{lll}
\hline Data & Data Source & Data Description \\
\hline Digital Elevation Model & USGS & Elevation, Overland, Channel, Slopes, Boundary \\
Soils Map & MWI & Soils Classification and Properties \\
Landuse Map & MWI & Land use classification; Cropland, forests, pasture etc \\
Climate Data & KMD & Daily Rainfall, Maximum and Minimum temperature \\
Streamflow & WARMA & Daily Streamflow (1976-2005) \\
\hline
\end{tabular}

Daily streamflow records $(\mathrm{m} 3 / \mathrm{s})$ at the Thwake River River gauging station No. 3FO2 and at the outlet of Subbasin 16, were obtained from the Water Resources Management Authority. The station has long enough flow records, but only the segment from January 1976 to December 2005, corresponding to the climate data, was used. Missing values of discharge were filled by Mike-11 NAM lumped hydrological model.

Table 2. SWAT parameters fitted during calibration and their final value ranges.

\begin{tabular}{|c|c|c|c|c|c|}
\hline \multirow{2}{*}{ S/No } & \multirow{2}{*}{ Parameter Description } & \multirow{2}{*}{ Parameter Code } & \multirow{2}{*}{ File } & \multicolumn{2}{|c|}{ Final Parameter Range } \\
\hline & & & & Min & $\operatorname{Max}$ \\
\hline 1 & SCS curve number & $\mathrm{CN} 2$ & .mgt & -0.3 & 0.3 \\
\hline 2 & Baseflow alpha factor & ALPHA_BF &. $\mathrm{gw}$ & 0 & 1 \\
\hline 3 & Soil evaporation compensation factor & ESCO & hru & 0 & 1 \\
\hline 4 & Groundwater revap coefficient & GW_REVAP &.$g w$ & 0 & 0.4 \\
\hline 5 & Manning's value for main channel & CH_N2 & .rte & 0 & 0.3 \\
\hline 6 & Soil bulk density & SOL_BD & .sol & -0.027 & 0.3 \\
\hline 7 & Groundwater delay & GW_DELAY & gw & 30 & 450 \\
\hline 8 & Threshold water depth in the shallow aquifer for flow & GWQMN &. $\mathrm{gw}$ & 0 & 1.88 \\
\hline 10 & Channel effective hydraulic conductivity & CH_K2 & .rte & 4 & 130 \\
\hline
\end{tabular}

The 1000 years (2049 to 3049) synthetic steam-flow for 3F02 was used in the WEAP model.

\subsection{Approach of the Modelling}

The behaviour of the Thwake system under the 1000's year of synthetic streamflows was explored in the model. The objective was not to explore the transitional commissioning phase of the Thwake system but how this system would behave once fully developed under the synthetic flows. The fully developed Thwake system is characterised below.

\subsubsection{Fully Developed Domestic Water Demand}

The demand on the reservoir was equal to the water supplied augmented by $5 \%$ to account for losses during the water treatment process before it is supplied to Wote and Konza.

\subsubsection{Fully Developed Hydropower Demand}

The purpose of the electricity production is first to activate the water pumps required for the Konza domestic water supply.

\subsubsection{Environmental Flow Requirement}

This was calculated from the monthly streamflow data for 61 years (1952-2012) for 3F02 gauging station. The data was set at $98 \%$ exceedance probability An environmental flow requirement was placed immediately downstream the dam. This requirement will have high priority so that the dam releases water to comply with this environmental requirement. 


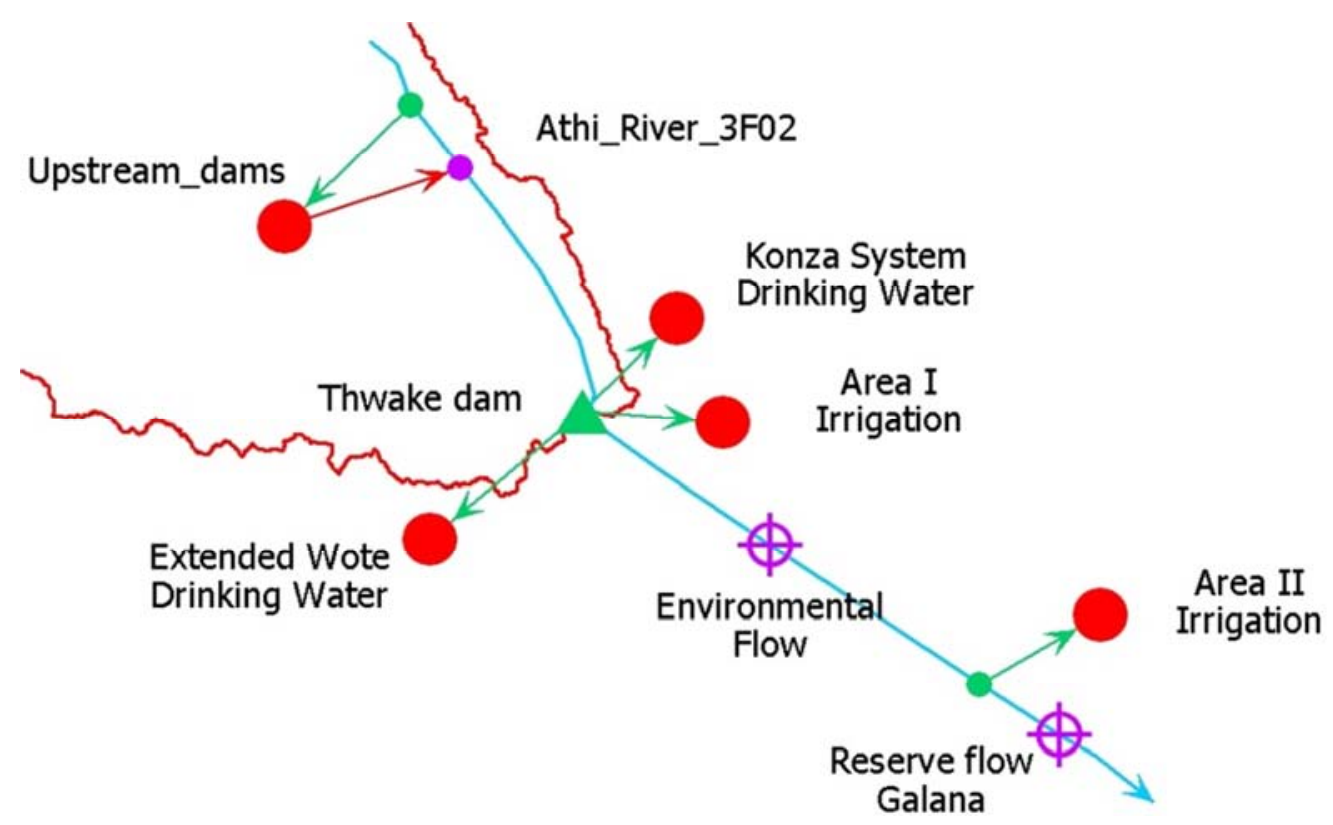

Figure 2. Schematic of the Thwake system in WEAP.

\subsubsection{Galana Flow Requirement}

The development of the large Galana Kulalu Irrigation Project has been considered in the model as a high priority. The Thwake dam should release water for this downstream scheme to satisfy what will be referred in this report as the "Galana flow requirement". This flow requirement was placed downstream of the intake for Irrigation Area II, as illustrated in Figure 4 above.

\subsubsection{Fully Developed Irrigation Water Demand}

The details of net irrigation area, crops and respective irrigation requirements were explored for the two irrigation areas, (area I and II).

\section{Results and Discussion}

\subsection{Model Calibration and Validation}

In the model, the current figures provide an actual picture of the situation hence it is viewed as a calibration step. The validation procedure was undertaken using the PEST routine within the WEAP system. PEST is a nonlinear parameter estimator and considered a unique calibration tool. The adjustment of sensitive parameters was done through trial and $\backslash$ error to determine the best value for a specific parameter. PEST utilizes a nonlinear estimation technique.

Table 3. Calibration and validation values.

\begin{tabular}{llll}
\hline Model Performance & R2 & NSE & Results \\
\hline Calibration & 0.67 & 0.62 & Acceptable \\
Validation & 0.62 & 0.61 & Acceptable \\
\hline
\end{tabular}

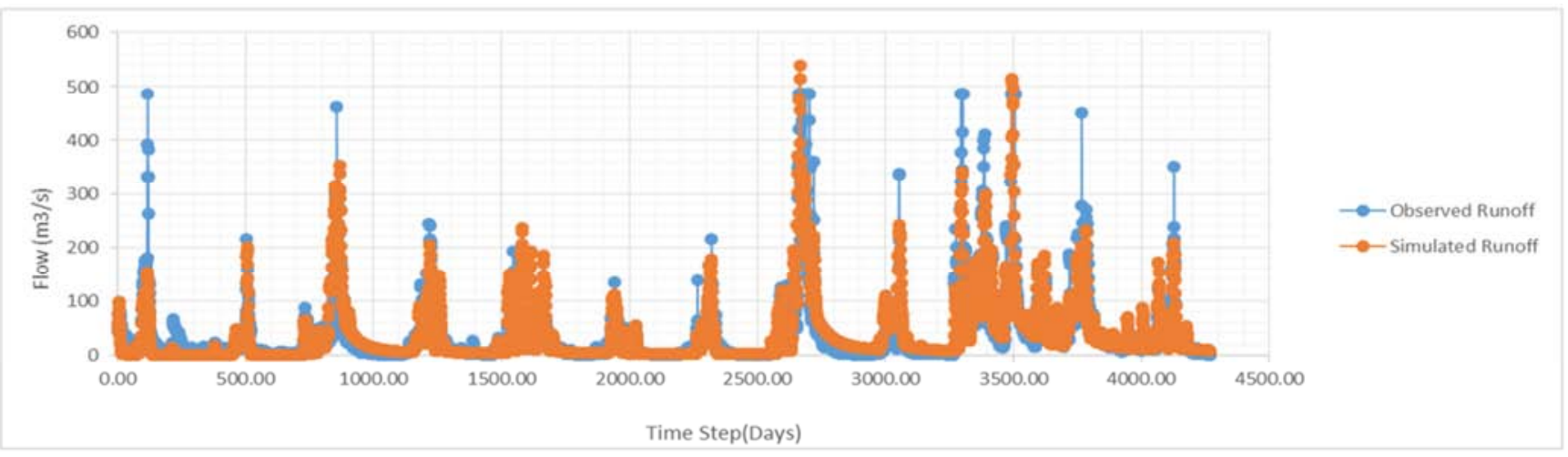

(a) 


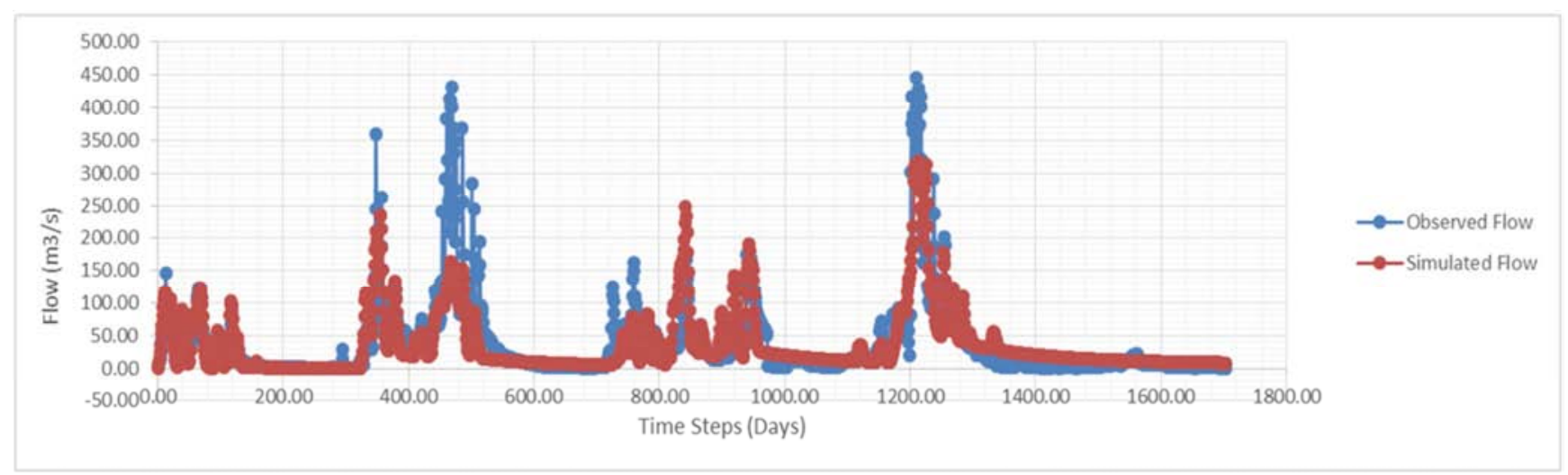

(b)

Figure 5. Plots of daily observed and simulated time series of streamflow with 95\% prediction uncertainty during; (a) calibration period (1968-1979), and (b) validation period (1980-1984).

Monthly streamflow data for the $3 \mathrm{FO} 2$ gauging station was divided into two periods: 18 years was used for model calibration (1968-1979), and the remaining 7 years (1980-1984) for validation. Few parameters were selected for the calibration process using GaussMarquart-Levenberg method, which saves time by doing fewer model runs.

\subsection{Inflow and Outflow Requirement for Thwake Reservoir}

The mean daily flow in a month for Athi River at RGS 3F02 is shown on table 4. These results are graphically depicted on figure 6. The results showed that Athi River at RGS 3F02 has an annual mean discharge of $34.04 \mathrm{~m}^{3} / \mathrm{sec}$.

Table 4. Mean daily flow in a month for RGS $3 F 02$.

\begin{tabular}{|c|c|c|c|c|c|c|c|c|c|c|c|c|}
\hline & Jan & Feb & Mar & Apr & May & Jun & Jul & Aug & Sep & Oct & Nov & Dec \\
\hline Mean Flow $\left(\mathrm{m}^{3} / \mathrm{s}\right)$ & 38.46 & 20.77 & 22.97 & 68.19 & 72.60 & 27.28 & 16.16 & 11.50 & 8.28 & 11.17 & 57.37 & 53.74 \\
\hline
\end{tabular}

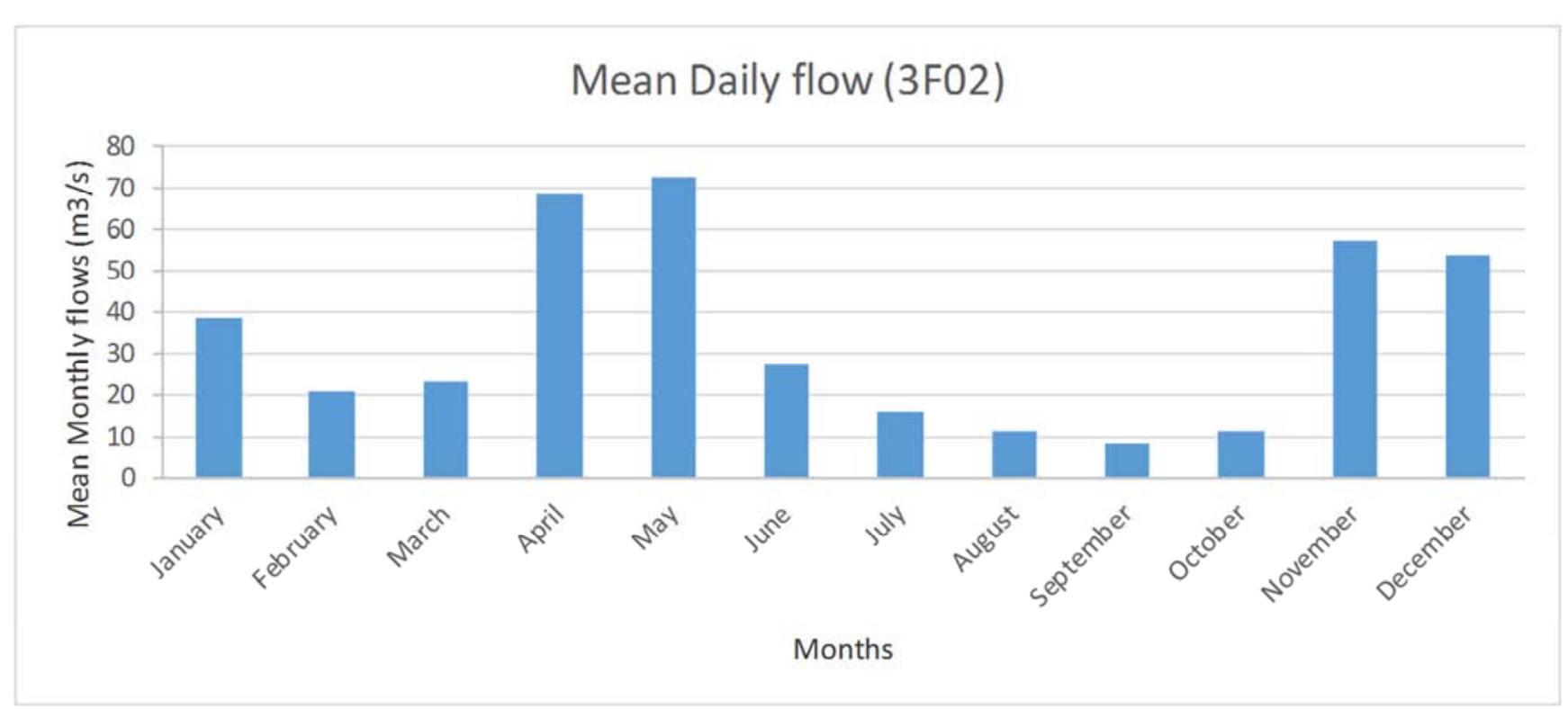

Figure 6. Mean daily flow in a month (3F02).

\subsection{Synthetic Flows (1000 Years)}

The 1000 years' synthetic flows were generated using SWAT. Digitised soil and land use maps of 2013 were obtained from the Ministry of Water and Irrigation. The land use map distinguishes eleven land use classes. Soil properties such as soil depth, texture and water holding capacity were obtained from JICA soil survey study of 1992 for the SWAT database. Details on land use and soil distribution are shown in figure 7 below. The data generated was for 2048 to 3047 years. Due to the technicality of WEAP not being able to deal with a $>2500$ year, the years were renamed to start from 1500 to 2499 , but the generated flows maintained. Thus the flow for 1500 corresponded to the flow of 2048 . 


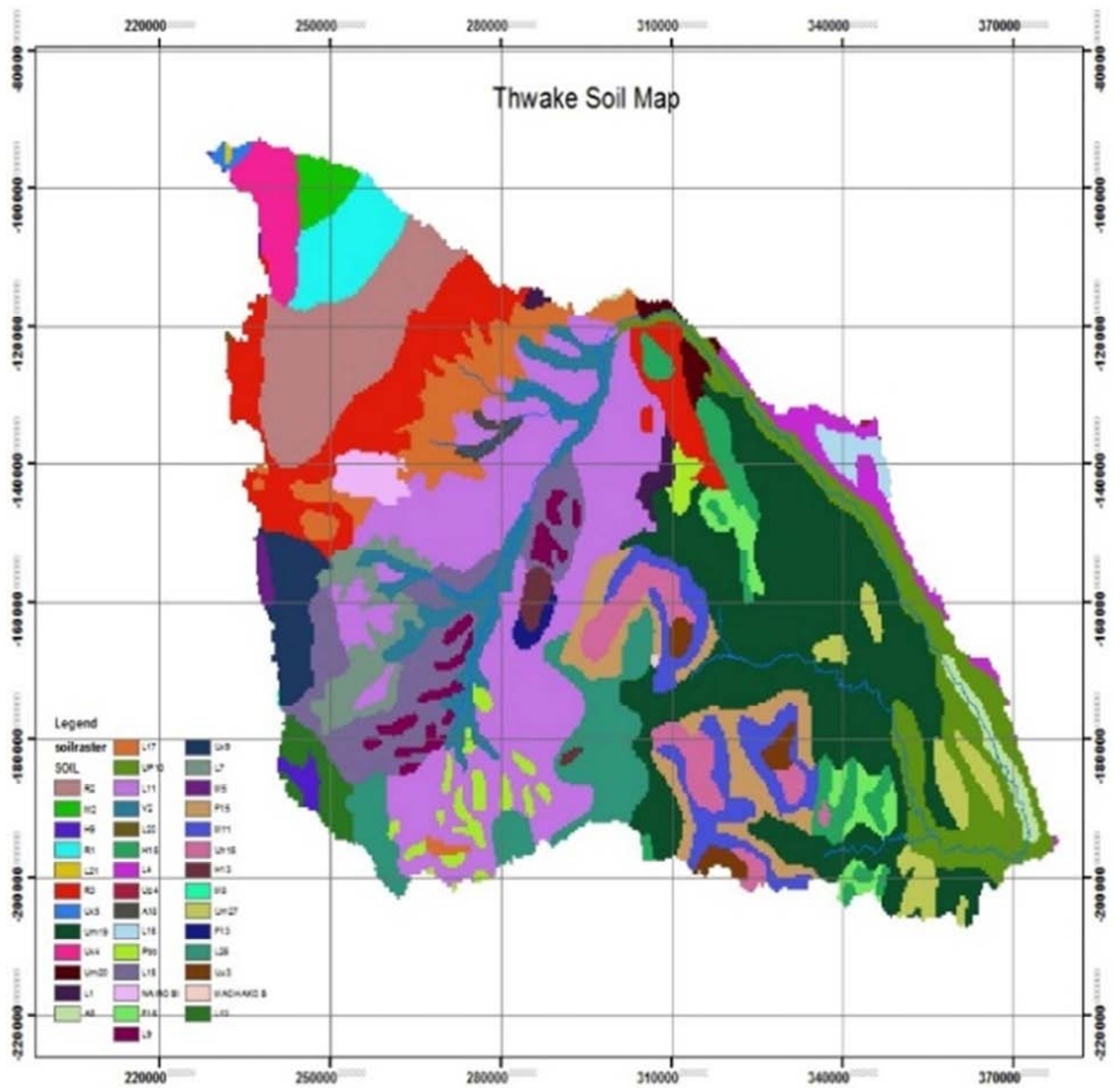

Figure 7. Soils dataset from MWI.

\subsection{Safe Yield of Thwake Reservoir}

Several scenarios were examined iteratively to identify the best operation rules and the tables below summarizes the best operation rule and the reservoir safe zone/yield for each development

Table 5. Results for Best Operation Rules and Safe reservoir zone for High priority Demands.

\begin{tabular}{|c|c|c|c|c|c|}
\hline Development & Scenario & $\begin{array}{l}\text { Priority for } \\
\text { Galana flow } \\
\text { requirement }\end{array}$ & Safe zone of the reservoir & $\begin{array}{l}\text { Zone totally } \\
\text { available for Galana } \\
\text { flow requirement }\end{array}$ & $\begin{array}{l}\text { Priority for filling/storing water in the } \\
\text { reservoir }\end{array}$ \\
\hline Base case, & 2.3.4bis & 2 (Option 2) & $\begin{array}{l}30 \% \text { of effective storage } \\
(897.0 \text { masl, } 341 \mathrm{Mm} 3)\end{array}$ & $\begin{array}{l}80 \% \text { of remaining } \\
\text { effective storage }\end{array}$ & $\begin{array}{l}3 \text { when water levels } \leq 897.0 \text { masl (ca } 341 \mathrm{Mm} 3) \text {, } \\
4 \text { when water levels } \leq 900.7 \text { masl (ca } 409 \mathrm{Mm} 3) \text {, } \\
5 \text { otherwise. }\end{array}$ \\
\hline Upstream Dam, & 3.3 .4 & 3 (Option 3) & $\begin{array}{l}30 \% \text { of effective storage } \\
(897.0 \text { masl, } 341 \mathrm{Mm} 3)\end{array}$ & $\begin{array}{l}80 \% \text { of remaining } \\
\text { effective storage }\end{array}$ & $\begin{array}{l}2 \text { when water levels } \leq 897.0 \text { masl (ca } 341 \mathrm{Mm} 3 \text { ), } \\
3 \text { when water levels } \leq 900.7 \text { masl (ca } 409 \mathrm{Mm} 3 \text {, } \\
4 \text { otherwise. }\end{array}$ \\
\hline
\end{tabular}


Table 6. Results for Best Operation Rules and Safe reservoir zone for Low priority Demands.

\begin{tabular}{|c|c|c|c|c|c|c|}
\hline Development & Scenario & $\begin{array}{l}\text { Priority for } \\
\text { Galana flow } \\
\text { requirement }\end{array}$ & $\begin{array}{l}\text { Safe zone of the } \\
\text { reservoir }\end{array}$ & $\begin{array}{l}\text { Zone totally } \\
\text { available for } \\
\text { Galana flow } \\
\text { requirement }\end{array}$ & Zone available for irrigation & $\begin{array}{l}\text { Priority for filling/storing } \\
\text { water in the reservoir }\end{array}$ \\
\hline $\begin{array}{l}\text { Base case, Low } \\
\text { Priority } \\
\text { Demands }\end{array}$ & 2.3.4.7 bis & 2 (Option 2) & $\begin{array}{l}30 \% \text { of effective } \\
\text { storage }(897.0 \\
\text { masl, } 341 \mathrm{Mm} 3)\end{array}$ & $\begin{array}{l}\text { Storage between the } \\
\text { safe zone and the } \\
\text { elevation } 900.7 \text { masl }\end{array}$ & $\begin{array}{l}\text { None: } 0 \% \text { of remaining storage, } \\
\text { partly: } 0 \% \text { of remaining storage, } \\
\text { totally: } 100 \% \text { of remaining } \\
\text { storage. }\end{array}$ & $\begin{array}{l}3 \text { when water levels } \leq 897.0 \\
\text { masl (ca } 341 \mathrm{Mm} 3), \\
4 \text { when water levels } \leq 900.7 \\
\text { masl (ca } 409 \mathrm{Mm} 3), \\
7 \text { otherwise. }\end{array}$ \\
\hline $\begin{array}{l}\text { Upstream } \\
\text { Dam, Low } \\
\text { Priority } \\
\text { Demand }\end{array}$ & 3.3.4.7 & 3 (Option 3) & $\begin{array}{l}30 \% \text { of effective } \\
\text { storage }(897.0 \\
\text { masl, } 341 \mathrm{Mm} 3)\end{array}$ & $\begin{array}{l}\text { Storage between the } \\
\text { safe zone and the } \\
\text { elevation } 900.7 \text { masl }\end{array}$ & $\begin{array}{l}\text { None: } 0 \% \text { of remaining storage, } \\
\text { partly: } 0 \% \text { of remaining storage, } \\
\text { totally: } 100 \% \text { of remaining } \\
\text { storage. }\end{array}$ & $\begin{array}{l}2 \text { when water levels } \leq 897.0 \\
\text { masl (ca } 341 \mathrm{Mm} 3), \\
3 \text { when water levels } \leq 900.7 \\
\text { masl (ca } 409 \mathrm{Mm} 3), \\
6 \text { otherwise. }\end{array}$ \\
\hline
\end{tabular}

\section{Conclusions}

From the study, different reservoir safe zones have been estimated as shown in the results section. Thwake reservoir has an estimated dependable yield when it will be in operation before and after the development of the upstream dams In practical terms of reservoir operation, these rules translate as follows:

For the base case scenario, at any water level, the water released through the turbine should be at minimum equal to the environmental flow. This should be possible even when only one turbine is operational (below 900.0 masl). In case it is not possible in particular cases (e.g., partial or total dysfunction of the turbine(s)), water should be released through the lower sluice so that the total flow downstream of the dam, through the turbine(s) and the lower sluice gate, equals the environmental flow requirement. The supply of domestic water to Wote should be also unrestricted.

When water levels in the reservoir is $\leq 897.0$ masl (ca. 341 $\mathrm{Mm} 3$ ), the environmental flow requirement and domestic water supply to Wote should be satisfied as mentioned above. For the rest, water is only partly released to the Konza domestic water supply demand and to the remaining hydropower water demand above the environmental flow requirement. The satisfaction of these demands is partial since the releases are restrained to preserve water storage in the reservoir. No water is released to satisfy the Galana flow requirement, as a complement to the water already released for hydropower, neither to the irrigation Area I and II.

When water level in the reservoir is between 897.0 masl (ca. $341 \mathrm{Mm} 3$ ) and 900.7 masl (ca $409 \mathrm{Mm} 3$ ), water releases for environmental flow requirement, supply of domestic water and for hydropower are unrestricted. Supply to satisfy the Galana flow requirement, as a complement to the water already released for Hydropower, is only partial to preserve water storage in the reservoir. No water is released to satisfy the irrigation Area I and II, as a complement to the water already released for hydropower and allocated to the Galana flow requirement.

When the level is above 900.7 , releases are unrestricted to all the water demands, i.e.:environmental flow requirement, the domestic water demands, the hydropower unit, the
Galana flow requirement, as a complement to the water already released for hydropower and to irrigation Area I and II, as a complement to the water already released for hydropower and allocated to the Galana flow requirement.

For the upstream dams development scenario, when water levels in the reservoir is below 897.0 masl (ca. $341 \mathrm{Mm} 3$ ), water is only partly released to the environmental flow requirement, domestic water supply demands and to the hydropower water demand. The satisfaction of these demands is partial since the releases are restrained to preserve water storage in the reservoir. The release for environmental flow should only complement the water being turbined, if needed at all. No water is released to satisfy the Galana flow requirement, as a complement to the water already released for Hydropower, neither to the irrigation Area I and II.

When water level in the reservoir is between 897.0 masl (ca. $341 \mathrm{Mm} 3$ ) and 900.7 masl (ca $409 \mathrm{Mm} 3$ ), satisfaction of environmental flow requirement and supply to the domestic water demands and to the hydropower unit are unrestricted. Supply to satisfy the Galana flow requirement, as a complement to the water already released for Hydropower, is only partial to preserve water storage in the reservoir. No water is released to satisfy the irrigation Area I and II, as a complement to the water already released for Hydropower and allocated to the Galana flow requirement.

When the level is above 900.7 , releases are unrestricted to all the water demands, i.e.: environmental flow requirement, the domestic water demands, the hydropower unit, the Galana flow requirement, as a complement to the water already released for hydropower, and to irrigation Area I and II, as a complement to the water already released for hydropower and allocated to the Galana flow requirement.

\section{References}

[1] S. Saxena and D. S. M. Yadav, "Application of Water Evaluation and Planning Model to Assess Future Water Demands of Surat City," p. 7, 2016.

[2] O. G. M. Metobwa, K. A. Mourad, and L. Ribbe, "Water Demand Simulation Using WEAP 21: A Case Study of the Mara River Basin, Kenya," Int. J. Nat. Resour. Ecol. Manag., pp. 9-18, 2018. 
[3] J. M. Nyika, G. N. Karuku, and R. N. Onwonga, "Water Balance for Mbagathi Sub-Catchment," J. Water Sustain., vol. 7, no. 3, pp. 193-203, 2017.

[4] SEI US, "Protecting tropical forest carbon stocks may not prevent large-scale species loss." Stockholm Environment Institute, 2009.

[5] A. T. Silva and M. M. Portela, "Generation of monthly synthetic streamflow series based on the method of fragments," 2011, pp. 237-247.

[6] D. C. A. Arselan, "Stream flow Simulation and Synthetic Flow Calculation by Modified Thomas Fiering Model," no. 4, p. 10, 2012.
[7] J. Jeong, N. Kannan, J. Arnold, R. Glick, L. Gosselink, and R. Srinivasan, "Development and Integration of Sub-hourly Rainfall-Runoff Modeling Capability Within a Watershed Model," Water Resour. Manag., vol. 24, no. 15, pp. 45054527, Dec. 2010

[8] CASSH, "Annex IV: Water and Sanitation Final design Report." Oct-2014.

[9] CASSH, “Annex V: Hydropower Design Report.," Dec-2013.

[10] Amiran, "Draft Pre-feasibility study Report," 2014.

[11] CASSH, "Component final design Report: Annex VI," 2013. 